\title{
頸＼cjkstart部（I ）199～205
}

\section{座長のまとめ}

\section{上村 卓也 (九州大学・耳鼻咽喉科)}

本群は，頸部に発生した珍しい良性腫瘍ないしは腫瘍 様病変の症例報告と, 血管腫および神経鞘腫の集計報告 である。

No. 199 : 松岡 (久留米大・耳) 他は 2 例の, No. 200 : 平林（信州大・耳）他は 1 例の頚動脈小体腫瘍を 報告した。後者に対して久留米大・栗田は, 術中の内頸 静脈, 迷走神経と腫瘍との関係，その処置について質問 した。平林は, 内頸静脈は腫瘍と別であり, 迷走神経, 舌下神経は腫瘍に入っていたが，これらはいずれも切断 したと答えた。

No. 201 : 松井（帝京大・耳）他は，頸部に発生する ことは極めて稀な Castleman リンパ腫の1例を報告し た。同様に頸部に生じることは珍しい aggressive fibromatosis のI例を No. 202 : 鵜飼 (名古屋大・口腔外科) 他は報告した。これに対し, 鈴木（新潟大・口腔外科） は腫瘍の骨原発の可能性と低分化型線維肉腫との区別に ついて質問した。これに対し，手術時に内側翼突筋と腫 瘍とに連続性が認められたので，筋膜由来と判断したと 答えた。

第 2 の質問は，乳児型線維肉腫がこの名称で呼ばれる こともあり，区别は無理であろう。
No. 203 : 清水（群馬ガンセンター・頭頸部）他は, 最近13年間に受診した頭頸部の血管腫55例の，性別，年 齢, 部位, 病理組織, 治療について報告した。これに対 し，進（佐賀医大・耳） 浮幼児の血管腫における手術 時期について質問した。清水は，機能障害のない場合に は治療に耐えられる時期迄待ち，適応を考慮に入れて行 う必要があると答えた。

No. 204 : 佐藤（北大・耳）他は最近10年間に経験し た神経鞘腫18例の集計結果を発表した。これに対し，大 森（倉敷中央・耳）は，原発神経を同定できた 8 例につ いて，その根拠を尋ねた。これに対し，佐藤は，術後に 出現した神経症状によったこと，および頸部交感神経由 来としたのは術後のホルネル症候によったことを答え た。

No. 205: 桐田（奈良医大 - 口腔外科）他は，3 歳女 児と45歳男性の下顎部に生じた 結節性筇膜炎を 報告し た。金平（愛知医大・歯科）の質問について佐藤は，第 2 例の腫湟は眼窩, 中頭蓋窩にも進入した大きなもので あったが, 経上顎的に被膜外摘出ができ, 視力, 視野狭 窄が改善したと答えた。 


\section{Carotid body tumor の 2 症例}

松岡 秀隆・栗田茂二朗・大久保 洋・平野 実 (久留米大学・耳番咽喉科)

Carotid body tumor は，1743年 Von Haller によ り初めて記載されて以来，現在まで約 800 例の報告があ る。本邦においては，1924年阿部が報告してから，約70 例の報告がみられる。今回我々は，2例の Carotid body tumor を経験したので報告する。

症例 1 は，18歳女性で主訴は右頸部腫瘤。1984年 4 月 頃より，右頸部の母指頭大の腫瘤に気づくも，自覚症状 ないため放置していた。1985年 5 月頃より，腫瘤の増大 傾向があり，更に圧痛も出現したため，9月某病院耳鼻 科受診し，11月12日良性腫瘍の疑いにて，当科に紹介さ れた。

初診時，右䜖動脈三角部に $4.5 \times 5.0 \mathrm{~cm}$ の弾性軟，表 面平滑で境界明瞭な腫瘤を触知した。軽度の圧痛を認め る以外，腫瘤自体に明らかな拍動はなく，血管雑音も聴 取していない。また，頸部リンパ節も触知していない。

12月 6 日局麻下に腫瘤摘出をはかったが，腫瘤は血管 に非常に富んでおり，総頸動脈との癒着が強く，Carotid body tumor を考え，手術を直ちに中止し，一旦創 を閉じた。

後日, 頸部 CT を施行した。enhance CT では, 総 莖動脈分岐部を中心に，血管に富む腫瘤が描出され，外 内頸動脈は腫演のなかにあると思われ，その境界は判別 出来なかった。

さらに，総頸動脈造影を施行した。動脈相では，内外 頸動脈の分岐部が搪大されており，その部を中心に腫瘍 が描出され，腫瘍は外垩動脈より栄養されていた。静脈 相では, 総頸動脈分岐部の下 $1.5 \mathrm{~cm}$ から頭蓋底に至る までの腫崵の濃染像がみられた。

血行再建の淮備を行い，12月16日全麻下に摘出術を行 った。腫鈞は血管に非常にとみ，頚動脈分岐部を中心に 全周性に頸動脈を取り囲んでいた。また迷走神経も腫瘍 に取り囲まれていた。まず，総到動脈の健常部より外膜 下に剝離を行い，外頚動脈を明視下に置き，頸動脈分岐 部直上で結紮した。さらに，腫陽を外膜下に内頸動脈， 迷走神経より剝離し摘出した。摘出腫瘍は，capsule に
被われ，表面は平滑であった。割面は，灰白色の充実性 腫演であり，点在性に血管の断端がみられた。組織は， Carotid body 由来の paraganglioma であった。 症例 2 は, 58歳男性。腫瘤の性状, 術前 $\mathrm{CT}$, 靧動脈 造影の所見では，腫愓は頸動脈分岐部を中心に頭蓋底近 くまで存在し，症例 1 と同様であった。

Carotid body tumor の診断のもとに, 全麻下に䜖動 脈外膜下で剝離をすすめ腫湯摘出をはかった。まず，外 頸動脈を結禁切断した。内頸動脈を剝離する途中に, 分 岐部より内頸動脈にかけて断裂がはいった。出血がひど いため，一旦血行を遮断し，分岐部を含めて腫瘍を摘出 し, 総頸動脈と内頸動脈の端々吻合を行った。血行遮断 の時間は25分間であり, 術後, 脳障害, 神経症状の合併 症はなかった。

Carotid body tumor の 2 例を経験して, 症例 1 より, 頸部腫瘤を主訴とした場合には，その頻度は低いが Carotid body tumor も常に念頭に置く必要があると痛感さ せられた。

Carotid body tumor の治療は, 手術的摘出が最良で 嵓る。Shamblin は本腫場を手術に際し, 次の 3 つに分 類している。

Group I：限局型で，頸動脈より容易に剝離しうる もの

Group II : 頸動脈々一部固着するも, Gordon-Taylar の Subadventitial dissection で摘除しうるもの。

Group III : 頸動脈分岐全周に固着し, 通常の方法で は摘除不可で, シャントの利用, 血管切除, 再建の必要 があるもの。

われわれの例は，症例 1 は Group II の subadventitial dissection で, 症例 2 は Group III で血管切除, 再建を必要とした。

2 例の手術を経験して, 手術に際しては, 血行再建の 準備をしてあたること，摘出に際しては，出来るだけ早 く，分岐部に達し，外莖動脈を結禁することが，出血を 少なくし，手術を容易にすると思われた。 


\section{0. 頸動脈小体腫瘍の 2 例}

平林 源・横山 晴樹 ・ 山本 香列

(信州大学・耳算咽喉科)

頸動脈小体腫瘍は本邦において60例余りの報告がみら れるにすぎず，比較的まれな疾患である。今回我々は頭 蓋底まで達し，内頸動脈とともに摘出した 1 例と，頸動 脈より剝離摘出した 1 例の, 合計 2 例を経験したので報 告した（1例汶抄録提出後に経験し，追如した）。

症例 1 は46歳男性。主訴は頸部腫瘤。

昭和55年 2 月, 左頸部の腫瘤に気づき, 某耳鼻科を受 診した。生検を試みたが，出血のため診断がつかず，放 置していた。その後腫瘤が増大するため, 昭和58年 6 月, 再度耳鼻科を受診し，当科を紹介された。

初診時左䫇部に径 $6 \times 3 \mathrm{~cm}$ の弹性硬の境界明膫, 表 面平滑な腫瘤を認め, また, 咽頭後壁の左側に膨隆を認 めた。CT にて頸椎と下顎骨の間に diffuse な腫貆陰影 がみられた。9 月 5 日入院し, 頸動脈造影を施行し, 莖 動脈分岐部の上方に tumor stain を認め, 内顓, 外頸 動脈が軽度圧排されていた。

以上の所見より, 莖動脈小体腫場を強く疑い, 11 月 28 日手術を施行した。しかし, 非常に出血し易く, 大出血 の危険があったため, 部分切除に終った。その後外来に て経過をみていたが，腫瘍は徐々に増大するため，昭和 61 年 1 月再入院となった。頸動脈造影にて総頸動脈は $\mathrm{C}_{6}$ 下端で閉塞し，頭蓋底まで達する tumor stain が 認められた。また, VAG で栄養血管は椎骨動脈と確認 された。なお，健側よりの頸動脈撮影にて，前交通動脈 経由の患側への血流は良好であった。そこで 2 月 10 日, 再度手術を試みた。まず，椎骨動脈よりの栄養血管を結 紮し，頭蓋底付近までを明視野に置き，内頸動脈を含め, 腫瘍を摘出した。術後, 意識障害, 片麻㾇などはみられ ていない。なお, 経過中血圧は正常で変動なく, 尿中カ テコラミンも正常範囲であった。

症例 2 は29歳男性, 主訴は頻部腫瘤。
昭和60年11月頃左頸部の腫瘤に気づき，昭和61年 2 月 当科受診した。初診時, 左頸部に径 $4 \times 4 \mathrm{~cm}$ の弾性軟, 表面平滑, 可動性の乏しい腫瘤を認めた。CT にて左内 頸静脈, 缅動脈の前内側に腫瘍陰影を認めた。頸動脈造 影はヨード過敏のため，施行できなかった。 5 月19日， 手術を施行した。腫瘍は頸動脈分岐部の上方に位置し， 内頸動脈を巻き込むように存在していた。腫場を内頸動 脈よりてい效いに剝離し，摘出した。

頚動脈小体腫湟の診断に関しては, CT も有効である が，頸動脈造影が最も有効である。腫瘍の大きさ，周囲 との位置関係の他に，手術の際参考となる栄養血管を知 ることができること,さらに，内頸動脈を犠牲にしなけ ればならない場合に，健側よりの血流状況を知ることが でき，欠くことのできない検査といえる。症例 1 では術 前に栄養血管が椎骨動脈の枝であることが確認されたた め，摘出に際し，その血流を遮断することによって，手 術が容易になった。症例 2 ではヨード過敏のため血管造 影ができず, 術前に本症を疑ったものの, 診断がつかな かった症例である。

治療に関しては，完全摘出が望ましいが，その際内頸 動脈の処理が問題となる。症例 2 は Shamblin らの分 類によると Group 2 に属するが, 内頸動脈から剝離摘 出し, 内頸動脈を保存できた。しかし, 腫愒が進展して いる場合には, 内頸動脈, 総頸動脈を損傷し, 生命に危 険を生ずることもある。そのために術前に血管造影を行 い，健側よりの血流の有無を確めておく必要がある。血 流が不十分の場合には代用血管も考慮しなければならな いであろう（症例 1 は, 腫瘍によって内頸動脈が完全に 閉塞した例であり，Group 3 に分類される。内頸動脈を 含めて摘出したが，健側よりの血流が十分であるので, 術後特に問題なく，現在に至っている)。 


\section{1. 頸部に発生した Castleman リンパ腫の 1 例}

\section{松井 和夫 (聖隷三方原病院・耳鼻咽唉科) 山 根 仁・五十風淑晴 (帝京大学・耳鼻咽喉科)}

Castleman リンパ䏦は1954年 Castleman がはじめて hyperplasia of mediastinal lymph nodes として報告し た特異な組織像を呈する疾患でその後 Castleman 自身 が localized mediastinal lymph node hyperplasia resembling thymoma としてさらに詳細に報告されたもの である。はじめは縦隔洞に限って認められていたが，乙 だいに胸胵外にも存在することが，報告されているが， 比較的まれである。今回我々は缅部に発生した症例を経 験したので報告する。

症例は10歳男性で, 主訴は右頸部腫瘤である。

約 1 年前に右頚部腫瘤に気づいていたが，放置してい た。最近増大傾向にあり，他院にて穿刺吸引細胞診を施 行され悪性ではないが, 診断は不明として, 帝京大学耳 兽咽喉科に紹介された。

昭和59年12月 27 日初診で, 右胸鎖乳突筋後縁に $4.0 \times$ $2.5 \mathrm{~cm}$ の表面平滑, 弾性やや軟の可動性良好の腫藘を 触れ, その周团と上深頸部に小腫瘤を 3 個触知した。鼻, 咽頭, 喉頭には異常を認めなかった。血液㭘査では特に 異常なく, WBC は $5100 / \mathrm{mm}^{3}, \mathrm{CRP}$ は (一), ESR も 1 時間值 $5 \mathrm{~mm}, 2$ 時間值 $13 \mathrm{~mm}$ と正常範囲であった。 ツベルクリン反応検查は $3 \mathrm{~mm} \times 8 \mathrm{~mm}$ であった。胸部 X-P も異常陰影を認めなかった。

超音波検查では輸郭整，充実性で内部エコーは均一で muscle 部分よりも hypoechoic pattern を示した。CT 検查では腫瘤は辺縁整で, enhancement 効果があった。 以上の所見から，覀性リンパ腫の可能性も否定はできな いが，良性の血管腫，炎症性リンパ節腫大などを考えて， 昭和 60 年 2 月 13 日全麻下に腫瘤摘出術を行った。

約 $5 \mathrm{~cm}$ の皮切を行い, 広頸筋を切断すると腫瘤に達 した。腫瘤は被膜を有していたが，裏面は小血管に富ん
でいた。摘出した腫瘤は赤裩色充実性で，大きさは $4 \mathrm{~cm}$ $\times 2.1 \mathrm{~cm} \times 1.1 \mathrm{~cm}$ だった。腫瘍に割面を入れた所見は髄 様, 微細顆粒状を呈していた。周因のリンパ節とは明ら かに異なっていた。迅速病理診で悪性所見はないとの辺 事であったので，腫瘤の周囲のリンパ節を同時に 2 個摘 出して，手術を終了した。

Castleman はこのリンパ腫の特徴として，(1) 滤胞の 增殖，(2) 求心性構造を有し, Hassall 小体様にみえる 濾胞中心，（3）濾胞内外の硝子化病巣，（4）濾胞間実質 に扝ける多数の毛細血管, その内皮細胞の増殖などをあ げている。摘出した標本はこれらの特徴を有していたの で, 病理診断は Castleman リンパ腫であった。

1972年 Keller らは臨床病理学的立場から本症を Hyaline vascular type と Plasma cell type に大別して いる。我々の症例は Hyaline vascular type でこれは Castleman リンパ腫の $91 \%$ 占め, 臨床的に血液所見に 異常を呈さないものが多い。

Castleman リンパ腫の本態については良性のリンパ 節腫瘤であるが，その病因については炎症説，腫瘍説，

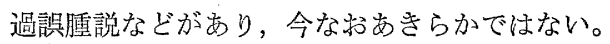

Castleman リンパ腫は現在までに200 例を越える報告 があり，本邦注いても60例以上が報告されている。そ のうち 頸部に 発生したものは胸腔内発生についで多い が，稀で本邦では21例の報告がみられるのみである。

莖部に発生した症例を検討すると，年齡は 7 歳から 60 歳で，性差はないようである。術前に診断するのは非常 に困難であるが, 本症の治療は外科的治療が唯一の治療 法である。腫瘤摘出後の再発はなく, 予後はきわめて良 好である。頸部腫瘤の鑑別診断に晾いて，考慮に入れる 必要があると思われるので，報告した。 


\title{
202. 顎下部に発生した Aggressive fibromatosis の 1 幼児症例
}

\author{
鵜 飼伸 - 金田敏郎 (名古屋大学・口腔外科) \\ 水野伸彦 (刚谷総合病院・歯科口腔外科) \\ 田口望 (名古屋大学附属病院分院 - 歯科口腔外科)
}

Aggressive fibromatosis は，浸潤性增殖を示すこと が特徴で, 組織学的には良性腫瘍に分類されているが, 臨床的には遠隔転移はないものの浸潤性発育や，しばし ば局所再発を認めることから悪性腫瘍に準じて取り扱わ れ, 口腔顔面領域では比較的稀な疾患とされている。

今回我々は, 左側顎角部内側に発症し, 顕著な開口障 害をきたした一幼児症例を経験したので報告した。

症例は, 初診時 1 歳11力月女览で, 主訴開口障害で あった。生後 9 カ月時, 転倒による左側頭部陌没骨折の 既往を認めたが, 家族歴に特記事項は認められなかった。

現病歴は，1歳 8 力月頃より開口障害を認めるように なり, 更に, 1 歳10カ月頃より左側顎下部に無痛性の腫 脹を認めるようになったため，1歳11力月時に某病院小 児科を受診し, biopsy の結果, fibromatosis と診断され 同病院からの紹介で当科を受診した。

初診時開口域は, 前歯間距離にて $5 \mathrm{~mm}$ で, 左側下䫟 角部内側に小鶏卵大の腫脹を認めた。触診により, 同部 位に非可動性で弾性硬の腫瘤を触知したが，圧痛は認め なかった。

X線所見では，左側下影角部骨質に $40 \times 20 \times 15 \mathrm{~mm}$ の 境界不明膫な舟喰虫様の骨吸収像を認めた。CT 所見に おいても，下頭板内側及び内側翼突筋を含むびまん性の 骨破壊像を認めた。

患者が幼児のため直ちに処置を行なわず，経過観察を したが，次第に骨吸収像は増大傾向を示し，開口域も 2 $\mathrm{mm}$ とその障害程度が進行してきたため, 昭和 58 年 6 月 10日手術を目的として入院した。

昭和58年 6 月 20 日 GOF 全麻下にて腫崵切除術を施 行した。手術時所見で, 腫癔は内側翼突筋と下顎枝内側 骨を破壞浸潤し上方へも進展していたが，下䫟板外側骨 は正常であった。母親の宗教上の理由により輸血ができ ず，患者が幼児であること，手術による顔貌変形が予想 されること, 本疾患が病理組織学的に良性であることを 考慮して腫癔を可及的に切除した。この処置により, 開 口域は $2 \mathrm{~mm}$ から $15 \mathrm{~mm}$ と改善した。

切除した腫瘍の病理組織学的所見では, 線維芽細胞は 豊富な膠原線維を伴って束状に増生していた。また, 墨
性像は認められず, 病理組織学的診断は Aggressive fibromatosis であった。

現在, 術後 2 年 8 カ月経過したが, X線写真にて腫瘍 切除部位に骨の増生が認められ, 病変部に隣接していた 左側下頡第二大臼歯歯胚の発育も順調であり, 腫貆の再 燃は認められなかった。

\section{考 察}

fibromatosis は, 良性の軟部組織腫䁑に含まれ, WHO によれば, 1. Fibromatosis NOS, 2. Cicatrical fibromatosis, 3.Keloid, 4.Nodular fasciitis, 5. Irradiation fibromatosis, 6. Penile fibromatosis, 7. Cervical fibromatosis, 8.Palmar fibromatosis, 9.Juvenile aponeurotic fibromatosis, 10. Planter fibromatosis, 11. Nasopharyngeal angiofibroma, 12.Abdominal wall desmoids, 13. Extra-abdominal desmoids（註 : NOS は亜型の記 載のないもの）と，13の組織型に分類されている。本症 例は, 臨床所見, 手術時所見, 病理組織学的所見等から, 内側翼突筋筋膜に発生した extra-abdominal desmoids すなわち Aggressive fibromatosis と考えられ，fibromatosis の中でも稀な疾患であった。

本疾患は, 遠城寺らの “本邦に打汀る良性軟部組織腫 瘍についての統計”によれば, fibromatosis 727例中74例 約10\%であり，その内，頭頸部領域にみられるものは74 例中10例，約 $13.5 \%$ と報告されているが，一方 Griffith らによれば，頭頸部領域での 発現頻度は，fibromatosis 中 $20 \%$ から $30 \%$ と報告されている。

今回我々の涉䍀し得艺範囲では, 本疾患の好発年齢は 10 代から 20 代で, 男性より女性汇多く, 再発率は20\%か ら50\%であった。

本疾患の治療は, 外科的切除が原則であり, Hunt ら は, 径 $3 \mathrm{~cm}$ 以下のものは長軸の 2 倍の幅をもって切除 し, $3 \mathrm{~cm}$ 以上また注発の場合は, 機能障害を避讨可 及的に切除することを提唱している。

現在, 術後 2 年 8 カ月経過し, 腫瘍の再然はみられな いが，先に述べた理由により腫瑒の可及的切除にとどめ ざるをえなかったことから，今後長期間にわたる慎重な 経過観察が必要であると考えている。 


\section{3. 頭頸部領域血管腫の臨床}

清水 龍一・佐竹 文介・牧野総太郎 - 松 浦 鎮

(群馬県がんセンター・頭頸部)

\section{目的}

頭頸部領域に発生した血管腫の臨床を検討し，今後の 治療の一助とすることを目的とした。

\section{方 法}

頭頸部領域血管腫の性別, 年齢, 発生部位, 病理組織, 治療方法等について臨床統計的観察を行った。

\section{対 象}

群馬県立がんセンター頭頸部において1972年から1985 年までの13年間に治療した頭頸部領域血管腫55例につい て検討した。

\section{結 果}

（1）男女差では55例中男性31例，女性24例とやや男性 優位であった。

（2）年齢別では $0 \sim 9$ 歳と60歳代にピークを示す 2 峰 性の分布を示した。

（3）部位別では舌13例，鼻腔12例，口唇12例，外耳 5 例, 顂粘膜 4 例, 中咽頭 4 例, 顔面頭部 3 例, 歯肉 2 例, 口腔底 2 例, 喉頭 2 例, 上顎洞 2 例であった。

(4) 病理組織別頻度は, 病理組織学的検索の行なわれ た40例中 Capillary hemangioma 30例, Venous hemangioma 4 例, Cavernous hemangioma' 3 例, Pyogenic granuloma 2 例, Arteriovenons hemangioma 1 例で あった。

（5）治療は表の如く単純切除23例, 冷凍手術10例, 桩 大手術 7 例, 単純切除+冷涷手術 2 例, 照射+単純切除 1 例, 未治療12例（うち経過観察 8 例）であった。部位 別治療内容では, 舌, 口唇では単純切除可能なものは単 純切除し, 切除しえないものは冷凍手術を行った。鼻腔, 上顎洞では桩大手術を必要とする場合が多かった。鼻腔 血管腫の小さなものは䍩純切除のみで十分であった。外 耳では美容上の問題もあり，小さなものは冷凍手術を行
ったが, 治療後醜形を残す場合には問題がなければ経過 観察を行う場合が多かった。全例を通じて照射に止血効 果を求めた例は 1 例のみであった。経過観察のみを行っ た例は 8 例であった。

\section{考 按}

頭頸部領域は機能の異なる様々な部位を有し，また美 容上の問題も大きいため, 治療にあたってはその発生部 位により適切な治療法の選択が重要である。ことに血管 腫はその名の如く血管より成る腫瘍であるため，良性腫 瘍にもかかわらず出血が問題であり，また腫崵と正常組 織との境界が不明瞭の場合が多いため, 治療に際しては 十分な注意と適正な治療法の選択が寛容である。

我々の治療方針は切除可能なむのはできる限り手術療 法を行い, 発生部位や大きさなどで切除に問題があると 思われる場合に泠涷手術を単独であるいは併用で用いて いる。

舌血管腫では, 単純切除できるものは切除したが, 腫 癔が舌中央に生じ切除しにくいものや，高齢者の場合に 冷凍手術を行った。切除しえない程大きなものにはあえ て舌半切除術等の拡大手術は行わず, 出血や機能障害の ない場合には経過観察を行った。

鼻副鼻腔血管腫ではことに出血に対する対処が重要で あるが，上顎部分切除を行った例でも出血量は中等度以 下であり，適正な手術操作を行えば出血に十分対処でき ると思われた。

血管腫の特徵に自然消退があり，ことに若年者におい ては十分な観察期間を置き，適当な時期を選んで治療の 適応を決めるべきである。

結 語

頭頸部領域血管腫は, その発生部位，大きさ，年齢な どにより適切な治療法の選択が重要である。

頭頸部領域血管腫部位別治療内別け（1972年～1985年）

\begin{tabular}{|c|c|c|c|c|c|c|c|c|c|c|c|c|}
\hline 治療 部位 & 舌 & 鼻腔 & 口唇 & 外耳 & 䎦頁粘腊 & 中呕的 & 钼面頭音 & 歯肉 & 口腔底 & 曒頭 & 上頶洞 & \\
\hline 単純切除 & 6 & 6 & 4 & & & 1 & 2 & 1 & 1 & 2 & & 23 \\
\hline 冷凍手術 & 3 & & 2 & 2 & 2 & 1 & & & & & & 10 \\
\hline 拡大手術 & & 3 & & & & 1 & & & 1 & & 2 & 7 \\
\hline 単純切除十冷凍手術 & & 2 & & & & & & & & & & 2 \\
\hline 照射＋単純切除 & & 1 & & & & & & & & & & 1 \\
\hline \multirow[t]{2}{*}{ 未治療 } & 4 & & & 3 & 2 & 1 & 1 & 1 & & & & 12 \\
\hline & 13 & 12 & 6 & 5 & 4 & 4 & 3 & 2 & 2 & 2 & 2 & 55 \\
\hline
\end{tabular}




\section{4. 当科における神経鞘腫症例}

佐藤 公輝・末永 通・田中 克彦

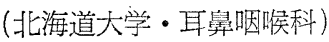

神経鞘腫は，Schwann 細胞由来の良性腫瘍であり， 一般には比較的稀な腫瘍である。

過去10年間に経験した頭攻部領域の神経鞘腫18例につ

いて検討した。

1975年より1985年の10年間に当科において診断を得た 頭頸部領域の神経靽腫は18例である。聴神経鞘腫は, 今 回の検討効象から除外した。18例の性別は, 男 9 例, 女 9 例であり性差はない。年齢は, 14歳から70歳まで, 平 均年齢は 39.4 歳である。

初診時の主訴は, 無痛性の単発性腫瘤がその60\%を占 める。神経症状を呈したのは中耳発生例の 2 例のみであ った。

発生部位別では，18例中 7 例, 約 $40 \%$ が頸部に発生し て㧍り，中でも側顓部の発生数が最も多かった。しかし ながら中咽頭, 舌, 口腔, 中耳等, 種々の部位に発生し ている。

一方，腫演の発生昌体となった神経を同定できたもの は計 8 例あり，半数の 4 例は迷走神経由来であった。

全例摘出手術を受けてお打り，その術中所見をスライ ドにまとめた。18例中13例は充実性であったが，2例は 雵胞椂であった。また，充実性腫瘤においても割面上大 小の震胞形成をみるものが 3 例あった。その他は, 鼻腔 のポリープ状腫瘤の 1 例と舌の小腫瘤 2 例である。

一方，18例中 9 例に腫瘤に連続する索状物を認めた。 この索状物は德湯の発生母体となった神経束である。確 認された 9 例のうち 4 例はその追跡中に不明となり, 腫 瘍より剝離し保存できたものは1例であった。残り 4 例 に抢いてはやむなく切断され, 中耳の 2 例には, 神経移 植を行った。

術後出現した症状は迷走神経麻痺 4 , 舌下神経麻瘦 1 , Horner 症候 1 である。神経移植を受けた中耳発生の 2 例では軽度の顔面神経不全麻疩が殘った。

また，全例，再発はなかった。

神経鞘腫は聴神経での登生が多いが, 頭䣆部領域もそ の好発部位である。Guptaによるとその $45 \%$ 頭頸部に 発生し, そのらちの $44 \%$ が側頸部に発生している。

発症年龄は10歳から60歳と幅広いが30歳台前後の例が
多く, 男女差はない。

一般には神経系腫瘍でありながら神経症状を欠く。 肉眼的には，単発生の被膜を有するよく境界された腫 瘍であり，種々の大きさの囊胞形成を伴うことがあり， Batsaki \& Cystic Schwannoma として述べている。 我々も，CT 上，懐胞像を呈した2例を経験した。1 例は左頸部，1例は右側咽頭である。2例とも，一様な 円形の Iow density を示し, 穿刺にても内容液の存在が 確認され，簬胞性疾患と思われたもので岕る。

一方, 囊胞形成の周囲には, Antoni B 型の組織像が しばしば認められるという。神経鞘腫が組織学的には Antoni A 型と Antoni B 型との混在であることを考 え合わせると，腫瘤内に多発する大小の囊胞を確認でき れば，術前診断の参考になると思われた。

今回の18例中にも, Echo 像にて腫瘤内に小さな囊胞 の多数が示唆されたものがあり，この症例は，術前に神 経䩪腫が疑われた。

神経鞘腫の治療流出術に限るが, 手術時, 腫瘍に連 続する神経束を確認することは困難な場合が少なくな く, 我々も確認できたのは 9 例で, さらに，保存しえた のは 1 例のみであった。また, 神経束の切断法可能な限 り避けなければならないが, 再発を防ぐためには, 腫湯 全摘を優先すべきと考える。

予後法きわめて良好であり，摘出が完全であれば再発 しないとされる。

\section{まとめ}

（1）性差はなく，30歳台前後の発症が多い。

（2）側頸部の発生が多いが, 中耳, 舌, 口腔, 咽頭, 喉頭, にも発生する。

（3）神経症状を呈することは少ない。

（4）単発性で，被膜を有するよく境界された腫演であ り，摘出は容易である。

（5）術中に両方向性の索状物を確認・追跡できれば診 断の参考になる。

（6）囊胞性疾患の臨床像を呈することがあり，注意を 要する。 


\section{5. 結節性筋膜炎の 2 例}

桐田 忠昭 - 望月 光治 - 医原 悦雄 - 吉川 文弘

植村 和嘉 - 岡田 征夫・杉村 正仁

(奈良医科大学・口腔外科)

Nodular fasciitis は皮下筋膜に生ずる反応性の良性病 変であるが，時に発育が迅速で組織像が線維肉腫に似る ため, 肉腫様筋膜炎, 皮下肉腫様線維腫症などとも呼ば れてきた。本症は四肢, 特に前腕部に好発するが, 頭頸 部領域にお叔る発生頻度は少なく, 全症例の約 $7 \%$ と報 告されている。今回, 我々は左側下䫁下縁部と煩部に発 生した nodular fasciitis の 2 症例を経験したので報告 する。

症例 1 : 患者は 3 歳女児。初診 3 カ月前より左側下䭭 下縁部の腫脹に気付き, 増大傾向を示したため当科受診 した。現症注左側下縁部に $24 \times 27 \mathrm{~cm}$ の無痛性, 弾性軟, 境界の比較的明膫な腫瘤を認めた。皮膚との癒着はなく, 表面に近い部分は可動性であるが, 深部は下顎下縁に癒 着していた。口腔内所見には異常は認められなかった。 初診時レントゲン像では, 左側下頡下縁部に辺縁不整, 境界明膫な 骨吸収像と外方に向う一部骨増生像がみら れ,骨原性肉腫の骨形成型であることも無視できず, 又他 の間葉系の悪性腫瘍をも疑い直ちに生検を施行した。そ の病理組織所見は, 紡鍂型の線維芽細胞が束状, 不規則 に増殖し，血管成分に富んだ部では赤血球，リンパ球の 多数遊出をみ, 周囲組織との境界は不明瞭であった。又, Mallory-Azan 染色により膠原線維の著明な增殖が確認 され, 以上より結節性筋膜炎と診断した。以後, 十分な 経過を追ったが, 臨床的には腫汮自体の増大傾向はなく, 影機能は正常で神経障害もみられなかった。又左側下效 下縁部表面は正常健康皮膚に被われ，同部のリンパ節に 大きな変化はみられなかった。8カ月後のレントゲン写 真では，骨吸収像に進展もみられず，骨増生が一部著明 となった。

症例 $2: 45$ 歳, 男性。初診 2 週間前より左煩部の腫脹 に気付き, その後徐々に増大してきたため当科紹介来院 した。現症は, 左口角より左方約 $35 \mathrm{~mm}$ の煩部を中心と して $\phi 22 \mathrm{~mm}$, 表面平滑, 弾性軟, 可動性の腫瘤を認め た。圧痛, 自発痛は共に認めず, 口腔粘膜にも異常は認 めなかった。良性腫富の診断の下に摘出術を施行した が, 組織の一部は下䅡骨膜とつながっていた。病理組織 所見は，線維芽細胞の紡錘型の核が一部で束状に並び,
毛細血管の增生と, それに伴う炎症細胞の遊出が見られ た。Mallory-Azan 染色によっても, 膠原線維の増殖が 強くみられ, 結節性筋膜炎と診断した。現在経過観察中 であるが再発は認められない。

結節性筋膜炎は反応性の血管, 線維芽細胞性増殖と考 えられ, 病変は主として浅在筋膜を侵し, 孤在結節を形 成するが，本態は良性の非腫瘍性疾患であり，線維腫症 の1つの型と分類されている。

本疾患の臨床的な特徴梳, 腫瘤が全く偶然気付かれ, 圧痛や自発痛を伴うことは少なく, 認めても極く軽度で, 明らかな誘因と思われるものは不明である。腫瘤の增大 速度は急速で, 一部緩徐なもの, あるいは不変である場 合むあるとされている。

原因については, 刺激説が有力で, 特に Soule らは 腫瘤が創治癒時の像によく似ていることや，上肢に多い ことなどから外傷刺激をあげ，それによる結合織の反応 性增殖とみている。また，放射線照射後，本疾患と同様 の病変が出現したという報告もあり, 明確な原因として は不明な点が多い。

年跲別発生頻度は，30歳代に好発し，男女差はほとん ど認められないが, 10歳未満の症例は非常に稀なもので, Stout は4.9\%であったと報告している。

頭頸部領域に和ける発生部位については, 顔面皮膚が 最も多く，なかでも下頻部と煩骨部に多い。これはこの 部が，すなわち咀嚼筋，ことに咬筋の起始部もしくは停 止部であり，外傷に対して易損性でしかもあらゆる刺激 を最も受けやすい部分であるためと考えられるからであ る。

治療および予後については, 通常腫瘤の周囲組織を含 めて切除することで十分で, 再発注ないと述べられてい るが，少数ではあるが再発例も報告されている。また， 自然消退をしたという報告も見うけられ，いずれにせよ 予後良好なものと言えよう。

本症例の第 1 症例は若年者であり, 正常なる額発育を 考慮し，積極的な切除は行わず十分な経過を追い，症例 2 においては切除摘出を施行し, 経過を追っているが大 増傾向, 再発は認められていない。 